\title{
Sensitivitas Bibit Jewawut (Setaria Italica (L.) P. Beauv) di Lahan Salin Pantai Cilacap
}

\section{Sensitivity of Foxtail Millet (Setaria Italica (L.) P. Beauv) Seedlings In Cilacap Coastal Saline Land}

\section{Normawati $^{1}$, Yugi R. Ahadiyat ${ }^{2}$, dan Totok Agung Dwi Haryanto ${ }^{3}$}

${ }^{1}$ Program Pascasarjana Fakultas Pertanian Universitas Jenderal Soedirman, J1. DR. Soeparno, Purwokerto Utara, 53122

${ }^{2}$ Laboratorium Agroekologi, Jurusan Agroteknologi, Fakultas Pertanian Universitas Jenderal Soedirman, Jl. DR. Soeparno, Purwokerto Utara, 53122

${ }^{3}$ Laboratorium Pemuliaan Tanaman, Jurusan Agroteknologi, Fakultas Pertanian Universitas Jenderal Soedirman, Jl. DR. Soeparno, Purwokerto Utara, 53122

*E-mail: ahadiyat.yugi@unsoed.ac.id

\begin{abstract}
The objectives of this study were to determine the criteria of foxtail millet seedlings in coastal area and the effects of $N, P, K$ fertilizer and water hyacinth ameliorant powder on growth characters of young foxtail millet plant in coastal saline land. The study was conducted at south coast, Bunton Village, Adipala District, Cilacap Regency in May-October 2019. Study in coastal saline land with factorial Randomized Complete Block Design with four replications. The treatment consisted of two factors, namely the dosage of $N, P, K$ fertilizer $(N, P, K=25 \%, 50 \%, 75 \%$, and $100 \%$ recommended dosage) and the water hyacinth powder ameliorant dose i.e. $0 t / h a, 1.5 t / h a$ and $2.5 t / h a$. Observation variables on seedling morphology viz. seedling height, leaf length, stem diameter, number of leaf and leaf greenness, and on.the field viz. plant height, number of leaf, fresh and dry root weights, total root length, and fresh and dry shoot weights. The results showed that good seedling criteria was. Plant height (24-26 cm), leaf length $(15-17 \mathrm{~cm})$, leaf number (3-6), stem diameter $(3,2-3,6 \mathrm{~cm})$ and leaf greeness (18,6-20,9 unit). Application of fertilizer dosages of $N, P, K 50 \%+$ without ameliorant gained the greater plant height of $62.76 \mathrm{~cm}$ and number of leaf of 7.28 than other treatments.
\end{abstract}

Keywords: ameliorant, foxtail millet, NPK, soil salinity

Disubmit : 4 Desember 2019; Diterima: 27 Desember 2019; Disetujui : 12 Januari 2020

\section{PENDAHULUAN}

Tanaman jewawut di berbagai wilayah Indonesia telah lama ada namun dewasa ini hampir terlupakan karena jarang ditemui dan lebih dikenal sebagai pakan burung. Meskipun demikian tetap masih ada beberapa daerah yang membudidayakan tanaman jewawut dalam skala kecil sebagai pangan pokok selain beras, salah satunya di Kabupaten Polewali Mandar dan Majene, Provinsi Sulawesi Barat (Sirappa \& Tim BPTP SULBAR 2015). Tanaman jewawut sangat berpotensi untuk dikembangkan secara luas dan memiliki potensi produksi sebesar 4 t/ha (Nurmala 2003).

Tanaman jewawut tergolong tanaman C4 dan dapat beradaptasi secara luas pada iklim tropik panas atau semi arid (Zooleh et al. 2011). Alih fungsi lahan pertanian ke lahan non pertanian menyebabkan berkurangnya jumlah lahan produktif sehingga diperlukan upaya perluasan lahan pertanian. Program ekstensifikasi oleh 
pemerintah direalisasikan pada lahan sub optimal (LSO) atau marjinal. Salah satu upaya ekstensifikasi dilakukan pada lahan salin (Barus 2013). Luas lahan di dunia yang dipengaruhi oleh tingginya salinitas kurang lebih 800 juta ha (FAO 2008).

Salinitas pada umumnya terjadi pada lahan yang berada dekat dengan pantai dan terjadi karena intrusi air laut ke daratan melalui permukaan tanah, tingginya evaporasi dan evapotranspirasi dibanding presipitasi atau curah hujan serta tingginya bahan induk tanah yang mengandung garam. Salinitas menjadi salah satu faktor yang menyebabkan rendahnya produksi tanaman karena terhambatnya penyerapan air dan nutrisi akibat jerapan Natrium pada pori tanah (Rachman et al., 2018). Upaya peningkatan ketersediaan hara dalam tanah khususnya di tanah salin dapat dilakukan melalui aplikasi pupuk anorganik tunggal berupa $\mathrm{N}, \mathrm{P}, \mathrm{K}$ dan amelioran alami.

Amelioran alami dapat dilakukan dengan memanfaatkan sumber daya hayati yang terdapat di lingkungan sekitar, salah satunya adalah eceng gondok. Eceng gondok merupakan jenis tanaman air yang dapat merusak lingkungan perairan karena pertumbuhannya yang sangat cepat (Stefhany et al. 2013). Eceng gondok sangat mudah didapat dan belum optimal dimanfaatkan dalam bidang pertanian, terutama sebagai amelioran yang dapat memperbaiki sifat fisik maupun kimia tanah. Pengkajian mengenai pemupukan N, P, K dinyatakan dapat memenuhi kebutuhan nutrisi dan meningkatkan hasil padi maupun palawija pada tanah yang tercekam salinitas (Iskandar \& Chairunas 2008). Selain pengaruh dari aplikasi pupuk, bahan alami juga berpengaruh terhadap proses pencucian $\mathrm{Na}^{+}$dan meningkatkan infiltrasi, stabilitas agregat tanah, kemampuan menyimpan air dan mengurangi penguapan (Tazeh et al. 2013). Hal tersebut menunjukan bahwa efektifnya bahan organik dalam menurunkan Daya Hantar Listrik (DHL) tanah (Gharaibeh et al. 2012). Pengaplikasian amelioran alami diharapkan mampu meminimalkan nilai DHL dan menetralkan nilai $\mathrm{pH}$ tanah sehingga ketersediaan dan penyerapan nutrisi dapat optimal bagi tanaman jewawut.

Anomali iklim berdampak buruk terhadap sistem usahatani di daerah pesisir pantai. Salah satu lahan pertanian yang memperoleh dampak langsung dari intrusi air laut adalah Desa Bunton, Kecamatan Adipala, Kabupaten Cilacap. Akibat dari pengaruh tersebut mayoritas lahan di daerah itu terancam berubah menjadi lahan tidak produktif. Umumnya pemanfaatan lahan salin di pesisir pantai Desa Bunton digunakan untuk budidaya tanaman padi, namun sejauh ini produksi masih belum optimal khususnya pada tanaman pangan berupa padi dan cekaman salinitas menjadi faktor utama pembatas terhadap penurunan produksi. Teknologi untuk memperbaiki sifat tanah salin yang diharapkan mampu meningkatkan produktivitas tanaman yang dibudidayakan, sehingga dapat mendukung program kerja pemerintah utamanya ketahanan pangan. Upaya menjaga ketahanan pangan harus bersinergi dengan diversifikasi pangan. Pelaksanaan diversifikasi pangan dapat diimplementasikan pada pengembangan komoditi pangan pokok, salah satunya melalui budidaya tanaman jewawut (Setaria italica (L.) P. Beauv). Guna meningkatkan pertumbuhan dan produksi tanaman jewawut pada lahan salin dibutuhkan aplikasi unsur hara yang tepat dan bahan amelioran alami yang dapat memperbaiki sifat fisika dan kimia tanah.

Penelitian ini bertujuan untuk mengetahui kriteria karakter morfologi bibit jewawut di area pesisir pantai serta mengetahui pengaruh dosis $\mathrm{N}, \mathrm{P}, \mathrm{K}$ dan amelioran eceng gondok terhadap karakter pertumbuhan tanaman jewawut muda di lahan salin pesisir pantai.

\section{METODE PENELITIAN}

Penelitian dilaksanakan pada bulan Mei sampai Oktober 2019 di Desa Bunton, Kecamatan Adipala, Kabupaten Cilacap, Jawa Tengah $\left(-7,6885^{\circ}, 109,144^{\circ}\right.$; Gambar 1). Berdasarkan hasil analisis tanah percobaan pada laboratorium Indonesian Center for Biodiversity and Biotechnology (ICBB) Bogor, tingkat salinitas atau daya hantar listrik (DHL) tanah adalah $0,21 \mathrm{mS} / \mathrm{cm}$, hasil tersebut tergolong kelas salinitas rendah berdasarkan jenis tanah pasir yaitu 0,15-0,28 dS/m (Hardie \& Doyle 2012). 


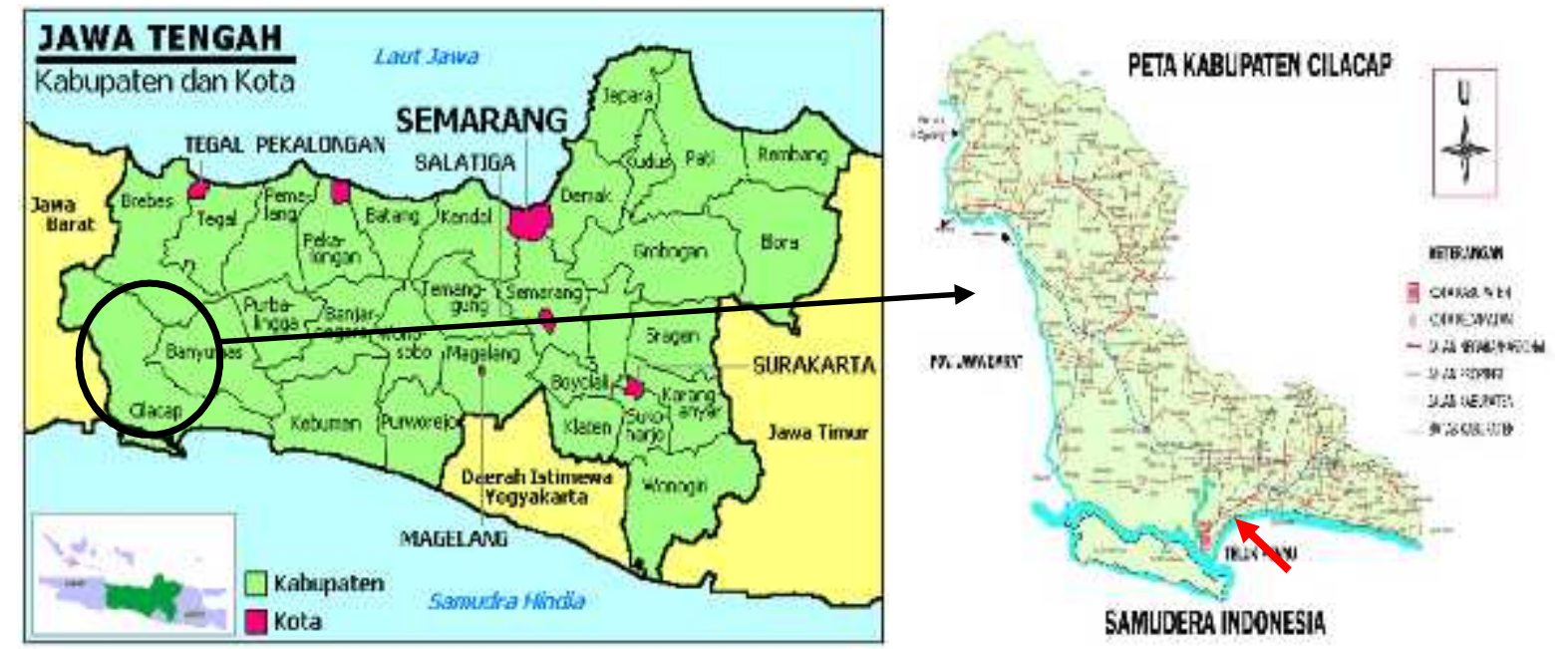

Gambar 1. Lokasi Percobaan di Desa Bunton, Kecamatan Adipala, Kabupaten Cilacap, Jawa Tengah

Penelitian dilakukan secara eksperimental melalui dua tahapan yaitu deskripsi kategori bibit jewawut yang disemai di daerah pesisir pantai dan karakter pertumbuhan jewawut umur muda ( 2 bulan). Pengamatan untuk deskripsi kategori bibit jewawut umur satu bulan didasarkan pada karakter tinggi bibit, panjang daun, jumlah daun, diameter batang, kehijauan daun. Penelitian di lahan salin pesisir pantai pada umur muda tanaman jewawut menggunakan Rancangan Acak Kelompok Lengkap terdiri atas dua faktor yaitu faktor pupuk NPK (28:11:8) dan faktor kedua amelioran serbuk eceng gondok. Faktor pertama adalah dosis pupuk NPK (28:11:8) dengan 4 taraf yang terdiri atas $25 \%, 50 \%, 75 \%$, dan $100 \%$ dosis rekomendasi. Dosis rekomendasi 100\% ditetapkan sebagai (140 kg N/ha, $55 \mathrm{~kg} \mathrm{P}_{2} \mathrm{O}_{5} / \mathrm{ha}$, dan $40 \mathrm{~kg} \mathrm{~K} 2 \mathrm{O} / \mathrm{ha}$ ). Faktor kedua adalah dosis amelioran serbuk eceng gondok dengan tiga taraf yang terdiri atas $0 \mathrm{t} / \mathrm{ha}, 1,5 \mathrm{t} / \mathrm{ha}, 2,5 \mathrm{t} / \mathrm{ha}$.

Penyemaian bibit dilakukan bersamaan dengan waktu kegiatan pengolahan lahan setelah itu kemudian pengaplikasian amelioran serbuk eceng gondok Eichhornia crassipes dan diinkubasi selama dua minggu sebelum bibit dipindah tanam. Pengamatan karakter morfologi bibit jewawut dilakukan satu kali saat sebelum bibit dipindah tanam dengan mengamati kategori pertumbuhan bibit melalui tinggi, panjang dan jumlah daun, diameter batang serta kehijauan daun, kehijauan daun diukur menggunakan alat SPAD 502 Plus Chlorophyll Meter.

Pengamatan pertumbuhan tanaman meliputi: tinggi dan jumlah daun. Pengamatan karakter pertumbuhan tanaman dilakukan pada umur 4 MST (Mingu Setelah Tanam). Pengamatan variabel destruksi yakni bobot basah akar, bobot kering akar, total panjang akar, bobot basah tajuk dan bobot kering tajuk dilakukan 1 kali pada saat tanaman jewawut berumur 2 MST (Minggu Setelah Tanam). Analisis data menggunakan program $S A S$ dan apabila berbeda nyata dilanjutkan dengan Duncan's Multiple Range Test(DMRT).

\section{HASIL DAN PEMBAHASAN}

\section{Karakteristik Morfologi Bibit Jewawut (Setaria italica (L.) P. Beauv) di Lahan Salin}

Pesisir Pantai. Salinitas mempengaruhi hampir seluruh tahap pertumbuhan terutama pada fase pembibitan dan pertumbuhan awal vegetatif dan pada umumnya dikatakan sebagai fase kritis tanaman pada lahan salin. Analisis karakteristik morfologi bibit jewawut menunjukkan 3 level morfologi berdasarkan kategori bibit. Pengamatan morfologi kategori bibit jewawut yang disemai di daerah pesisir pantai dapat dilihat pada Tabel 1 dan Gambar 2 berikut: 
Tabel 1. Karakter Pertumbuhan Tanaman Jewawut Pada Level Bibit

\begin{tabular}{cccccc}
\hline Kategori & $\begin{array}{c}\text { Tinggi bibit } \\
(\mathrm{cm})\end{array}$ & $\begin{array}{c}\text { Panjang daun } \\
(\mathrm{cm})\end{array}$ & $\begin{array}{c}\text { Jumlah daun } \\
\text { (helai) }\end{array}$ & $\begin{array}{c}\text { Diameter batang } \\
(\mathrm{cm})\end{array}$ & $\begin{array}{c}\text { Kehijauan } \\
\text { (unit) }\end{array}$ \\
\hline B & $24-26$ & $15-17$ & $3-6$ & $3,2-3,6$ & $18,6-20,9$ \\
CB & $17-22$ & $12-14$ & $4-5$ & $2,1-3,1$ & $14,4-17,9$ \\
KB & $15-22$ & $10-13$ & $3-4$ & $2,1-3,5$ & $6,0-13,5$ \\
\hline
\end{tabular}

Keterangan: $\mathrm{B}=$ baik; $\mathrm{CB}=$ cukup baik; $\mathrm{KB}=$ kurang baik

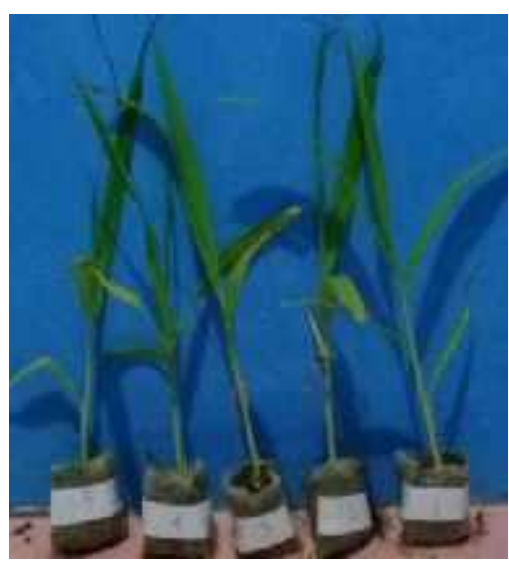

Gambar 2a. Bibit Jewawut (Kategori Baik)

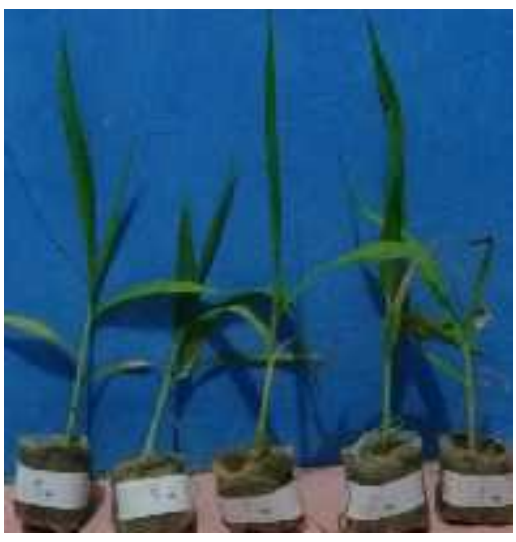

Gambar 2b. Bibit Jewawut (Kategori Cukup Baik)

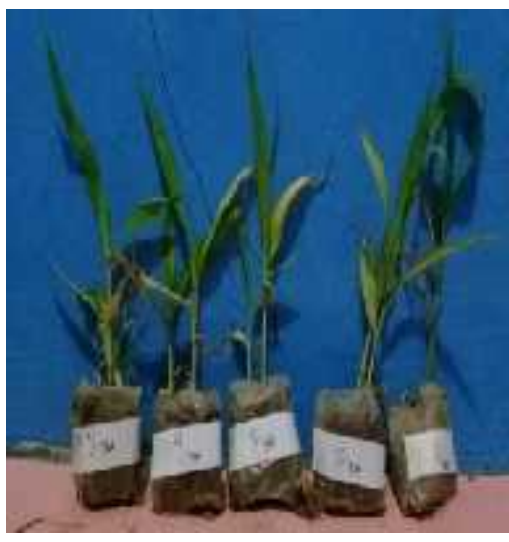

Gambar 2c. Bibit Jewawut (Kategori Kurang Baik)

Hasil pengamatan kategori bibit menghasilkan tiga ketegori, Baik, Cukup Baik dan Kurang Baik pada Tabel 1. dan gambar 2a, $2 \mathrm{~b}$ dan $2 \mathrm{c}$ menunjukkan nilai tertinggi dan terendah pada masing-masing variabel karakter bibit. Variabel tinggi bibit tanaman kategori Baik pada kisaran 24-26 cm, panjang daun bibit yang baik pada kisaran $15-17 \mathrm{~cm}$, diameter batang 3,2-3,6 cm, jumlah daun 3-6 helai dan kehijaun daun berada pada kisaran 18-21 unit.

Beranekaragamnya pertumbuhan bibit tanaman yang meliputi tinggi tanaman, panjang daun, diameter batang, jumlah daun dan tingkat kehijauan daun disebabkan oleh berbagai macam masalah satu hal yang menjadi inti adanya pengaruh cekaman osmotik yang menyebabkan tanaman sulit menyerap air dan pengaruh dari ion $\mathrm{Na}^{+}$dan $\mathrm{Cl}^{-}$yang bersifat meracuni tanaman, sehingga pembelahan dan pembesaran sel menjadi lambat dan mengakibatkan tanaman tumbuh kerdil. Pembibitan merupakan tahap awal yang penting dalam budidaya tanaman. Pengujian ketahanan terhadap salinitas dimulai saat masa pembibitan guna mengetaui dan mendapatkan kualitas pertumbuhan bibit yang baik dan toleran terhadap cekaman salinitas. Fase bibit sangat rentan terhadap kondisi cekaman salinitas sehingga pada beberapa bibit terdapat juga yang tidak toleran, namun masing-masing tanaman memiliki ketahanan dan daya adaptasi yang berbeda-beda (Kusumiyati et al. 2017). Dalam suatu kondisi tercekam dapat memacu bibit jewawut untuk beradaptasi menjadi tidak toleran bahkan menyebabkan kematian. Sopandie (2013) menyatakan bahwa adaptasi tanaman dilahan pesisir pantai dapat menyebabkan penurunan jumlah daun, sehingga dapat mempengaruhi proses metabolisme tanaman diantaranya pada penurunan pembesaran dan pembelahan sel, produksi protein, serta penambahan biomassa tanaman. Selain itu, hal tersebut menandakan terhambatnya tinggi suatu tanaman pada cekaman salinitas disebabkan sedikitnya jumlah kandungan air dalam jaringan sehingga terganggunya aktivitas meristem apikal dalam pertumbuhan dan perkembangan sel tanaman (Kurniasari et al. 2010).

Pada pengamatan jumlah daun dan diameter batang menunjukkan rentang penurunan yang cukup signifikan pada awal pengamatan. Hal tersebut disebabkan jerapan garam dalam jaringan tanaman sehingga menurunkan potensial air. Menurunnya potensial air mengakibatkan tanaman sulit untuk menyerap yang berakibat pada pertumbuhan tidak normal. Potensial air yang rendah juga berakibat pada terhambatnya pembentukan dan pembesaran sel-sel yang medukung pertumbuhan batang dan direspon pula melalui Hal 51 Volume 20 Nomor 1 Tahun 2020 
terhambatnya pembentukan daun. Dachlan et al. (2013) menyatakan bahwa penurunan turgor dan potensial air tanaman dengan penutupan stomata sehingga menurunkan pertumbuhan tanaman, keadaan tersebut disebabkan oleh adanya molekul $\mathrm{NaCl}$ yang mengalami ionisasi menjadi $\mathrm{Na}^{+}$dan $\mathrm{Cl}^{-}$yang menginduksi terjadinya stress ion mengakibatkan pertumbuhan dan perkembangan sel tanaman terhambat. Pranasari et al. (2012) mengungkapkan bahwa semakin menurun tingkat kehijauan daun menyebabkan penurunan fotosintat akibat salinitas, sehingga tekanan turgor yang menurun menyebabkan stomata tertutup dan $\mathrm{CO}_{2}$ yang digunankan untuk proses fotosintesis menurun.

Pengaruh Aplikasi Dosis Pupuk N, P, K dan Amelioran Alami pada Karakter Pertumbuhan Tanaman Jewawut di Lahan Salin Pesisir Pantai. Pengaruh aplikasi pupuk N, P, K pada variabel tinggi tanaman menunjukkan hasil berbeda nyata, aplikasi amelioran menunjukkan pengaruh berbeda sangat nyata, interaksi aplikasi pupuk N, P, K dan amelioran menunjukkan pengaruh sangat berbeda nyata. Pengaruh pupuk N, P, K pada variabel jumlah daun tidak berbeda nyata, aplikasi amelioran berpengaruh sangat berbeda nyata, dan interaksi aplikasi pupuk N, P, K dan amelioran sangat berbeda nyata. Pada variabel karakter pertumbuhan lainnya yaitu bobot akar basah, bobot akar kering, total panjang akar, bobot tajuk basah dan bobot tajuk kering menunjukkan pengaruh tidak berbeda nyata pada aplikasi pupuk $\mathrm{N}, \mathrm{P}, \mathrm{K}$ dan amelioran maupun interaksi kedua perlakuan (Tabel 2).

Tabel 2. Hasil analisis sidik ragam terhadap variabel pertumbuhan dan hasil

\begin{tabular}{|c|c|c|c|c|}
\hline \multirow{2}{*}{ No } & \multirow{2}{*}{ Variabel Pengamatan } & \multicolumn{3}{|c|}{ Perlakuan } \\
\hline & & $\mathrm{P}$ & A & PxA \\
\hline \multicolumn{5}{|c|}{ Karakter Pertumbuhan } \\
\hline 1 & Tinggi Tanaman & $*$ & $* *$ & $* *$ \\
\hline 2 & Jumlah Daun & tn & $* *$ & $* *$ \\
\hline 3 & Bobot Akar Basah & tn & tn & tn \\
\hline 4 & Bobot Akar Kering & tn & tn & $\operatorname{tn}$ \\
\hline 5 & Total Panjang Akar & tn & tn & tn \\
\hline 6 & Bobot Basah Tajuk & tn & tn & $\operatorname{tn}$ \\
\hline 7 & Bobot Kering Tajuk & tn & tn & tn \\
\hline
\end{tabular}
uji $\mathrm{F}(p=1 \%) . \mathrm{P}=$ dosis pupuk $\mathrm{N}, \mathrm{P}, \mathrm{K}, \mathrm{A}=$ dosis ameliorant

Pupuk N, P, K dapat meningkatkan tinggi tanaman karena merupakan unsur essensial yang dibutuhkan pada pertumbuhan tanaman. Aplikasi amelioran menunjukkan hasil berbeda sangat nyata pada variabel tinggi dan jumlah daun. Hal tersebut menegaskan bahwa bahan organik mampu mempercepat pencucuian Na+ dan meminimalkan DHL tanah salin karena bahan organik memiliki kemampuan untuk meningkatkan infiltrasi dan stabilitas agregat tanah, menahan air dan mengurangi penguapan sehingga mampu mendukung penyerapan hara (Mahdy 2011). Tanaman jewawut yang mengalami cekaman salinitas menunjukkan respon penurunan secara perlahan pada pertumbuhan atau organ vegetatif. Nekrosis merupakan salah satu dampak yang ditunjukkan secara visual pada cekaman salinitas berupa daun menguning secara perlahan, mengering kemudian mati. Dampak tersebut disebabkan tingginya paparan uap air laut yang mengandung garam kemudian melekat pada daun, ion garam menutupi stomata sehingga menyulitkan tanaman untuk menangkap Karbondioksida (CO2) guna melangsungkan fotosintesis. Menurunnya pertumbuhan tanaman pada cekaman salinitas disebabkan penyerapan $\mathrm{Na}+$ dan $\mathrm{Cl}$ - diatas batas optimum dan mengakibatkan keracunan (toksisitas ion spesifik), Na merupakan unsur non esensial namun tetap dibutuhkan tanaman, sedangkan $\mathrm{Cl}$ merupakan hara mikro esensial, kedua ion tersebut akan terakumulasi pada daun dan bersifat toksik jika konsentrasinya berlebihan (Taufiq et al. 2015). Hasil analisis dapat dilihat pada Tabel 3 berikut. 
Tabel 3. Pengaruh aplikasi pupuk N, P, K dan amelioran alami terhadap karakter pertumbuhan tanaman jewawut pada umur 2 MST (Minggu Setelah Tanam)

\begin{tabular}{cccccc}
\hline \multirow{2}{*}{ Perlakuan } & \multicolumn{7}{c}{ Variabel Pengamatan } \\
\cline { 2 - 6 } & BBA $(\mathrm{g})$ & BKA $(\mathrm{g})$ & TPA $(\mathrm{cm})$ & $\mathrm{BBT}(\mathrm{g})$ & $\mathrm{BKT}(\mathrm{g})$ \\
\hline Dosis Pupuk N, P, K (\%) & $0,25 \mathrm{a}$ & $0,06 \mathrm{a}$ & $77,63 \mathrm{a}$ & $1,95 \mathrm{a}$ & $0,35 \mathrm{a}$ \\
25 & $0,20 \mathrm{a}$ & $0,07 \mathrm{a}$ & $60,88 \mathrm{a}$ & $1,57 \mathrm{a}$ & $0,25 \mathrm{a}$ \\
50 & $0,31 \mathrm{a}$ & $0,08 \mathrm{a}$ & $72,79 \mathrm{a}$ & $1,81 \mathrm{a}$ & $0,37 \mathrm{a}$ \\
75 & $0,16 \mathrm{a}$ & $0,08 \mathrm{a}$ & $58,75 \mathrm{a}$ & $1,12 \mathrm{a}$ & $0,20 \mathrm{a}$ \\
100 & & & & & \\
\hline Dosis Amelioran (t/ha) & $0,23 \mathrm{a}$ & $0,06 \mathrm{a}$ & $63,81 \mathrm{a}$ & $1,54 \mathrm{a}$ & $0,29 \mathrm{a}$ \\
1,5 & $0,24 \mathrm{a}$ & $0,08 \mathrm{a}$ & $69,69 \mathrm{a}$ & $1,75 \mathrm{a}$ & $0,33 \mathrm{a}$ \\
2,5 & $0,22 \mathrm{a}$ & $0,08 \mathrm{a}$ & $69,03 \mathrm{a}$ & $1,55 \mathrm{a}$ & $0,27 \mathrm{a}$ \\
\hline KK $(\%)$ & 12,95 & 3,90 & 18,33 & 12,30 & 15,50 \\
\hline
\end{tabular}

Keterangan : Angka yang diikuti huruf yang sama pada kolom dan perlakuan yang sama menunjukkan tidak berbeda nyata pada Uji $D M R T(p=5 \%)$. BBA= Bobot Basah Akar, BKA= Bobot Kering Akar, TPA= Total Panjang Akar, BBT= Bobot Basah Tajuk, BKT= Bobot Kering Tajuk.

Hasil analisis pengamatan yang dilakukan dengan metode destruksi (Tabel 3) tidak berbeda nyata. Hal itu menunjukkan terhambatnya penyerapan hara dan air yang dibutuhkan tanaman. Aplikasi pupuk N, P, K dan amelioran alami tidak dapat mempengaruhi variabel tersebut disebabkan cekaman salinitas yang berada pada tanah dan pengaruh uap air laut yang mengandung garam terpapar langsung ketanaman. Rewald et al. (2013) menyatakan bahwa perubahan anatomi akar dan tajuk tanaman pada cekaman salinitas merupakan salah satu penentu toleransi tanaman terhadap cekaman salinitas. Salinitas berpengaruh terhadap penurunan kemampuan penyerapan air, hara dan fotosintesis sehingga mengganggu pertumbuhan tanaman. Paparan salinitas baik dari tanah dan uap air laut dapat menekan proses pertumbuhan tanaman dengan menghambat pembesaran dan pembelahan sel, produksi protein serta penambahan biomassa tanaman. Anandia et al. (2014) menyatakan bahwa cekaman salinitas kurang menguntungkan bagi tanaman karena akan menurunkan potensial air larutan tanah, natrium dan juga ion-ion lainnya apabila terlalu banyak akan menjadi racun bagi tanaman. Hal tersebut berdampak pula pada jumlah tanaman yang mengalami senescence akibat cekaman. Hal tersebut terjadi karena kadar salinitas yang meningkat, baik itu pada tanah juga pada atmosfer berupa uap air garam, sehingga pertumbuhan panjang akar, bobot akar maupun bobot brangkasan menjadi tidak optimal (Amirjani 2010). Dampak salinitas pada pertumbuhan akar yang disebabkan meristem akar sangat sensitif terhadap mineral garam akibat pembelahan sel secara mitosis berlangsung sangat tinggi dalam pertumbuhan akar, terganggunya pertumbuhan akar juga berdampak pada rendahnya produksi auksin yang dapat mendukung pertumbuhan akar Kusumiyati et al. (2017).

Pengamatan pertumbuhan tanaman meliputi: tinggi dan jumlah daun. Pengamatan karakter pertumbuhan tanaman dilakukan secara rutin dengan interval 1 minggu. Pengamatan variabel destruksi yakni bobot basah akar, bobot kering akar, total panjang akar, bobot basah tajuk dan bobot kering tajuk dilakukan 1 kali pada saat tanaman jewawut berumur 2 MST (Minggu Setelah Tanam). Analisis data menggunakan program $S A S$ dan apabila berbeda nyata dilanjutkan dengan Duncan's Multiple Range Test(DMRT). 
Tabel 4. Pengaruh Aplikasi Pupuk N, P, K dan Amelioran Alami Terhadap Tinggi Tanaman dan Jumlah Daun Jewawut pada Umur 4 MST (Minggu Setelah Tanam)

\begin{tabular}{|c|c|c|c|c|}
\hline Pupuk N, P, K (\%) & Amelioran (t/ha) & Tinggi tanaman $(\mathrm{cm})$ & Jumla & a daun \\
\hline \multirow{3}{*}{25} & Tanpa ameliorant & $31.32 \mathrm{de}$ & 3.75 & $\mathrm{de}$ \\
\hline & 1,5 & $31.01 \mathrm{de}$ & 4.08 & cde \\
\hline & 2,5 & $40.78 \mathrm{~cd}$ & 5.18 & bcd \\
\hline \multirow{3}{*}{50} & Tanpa ameliorant & $62.76 \quad \mathrm{a}$ & 7.28 & $\mathrm{a}$ \\
\hline & 1,5 & $18.50 \mathrm{e}$ & 2.93 & $\mathrm{e}$ \\
\hline & 2,5 & $45.07 \mathrm{bcd}$ & 5.65 & abcd \\
\hline \multirow{3}{*}{75} & Tanpa ameliorant & $58.25 \mathrm{ab}$ & 6.85 & $a b$ \\
\hline & 1,5 & $42.93 \mathrm{~cd}$ & 4.98 & bcd \\
\hline & 2,5 & $30.62 \mathrm{de}$ & 4.18 & cde \\
\hline \multirow{3}{*}{100} & Tanpa ameliorant & $47.75 \quad b c$ & 5.75 & $\mathrm{f}$ \\
\hline & 1,5 & $38.84 \mathrm{~cd}$ & 4.65 & cde \\
\hline & 2,5 & $34.46 \mathrm{~cd}$ & 5.45 & abcd \\
\hline
\end{tabular}

Keterangan: Angka yang diikuti dengan huruf yang sama pada kolom yang sama menunjukan tidak berbeda nyata pada uji $\operatorname{DMRT}(p=5 \%)$.

Hasil analisis variabel pertumbuhan (Tabel 4) menunjukkan hasil tinggi tanaman sangat berbeda nyata pada perlakuan N, P, K 50\% + tanpa amelioran dengan tinggi 62,76 cm dan diikuti dengan perlakuan N, P, K $75 \%$ + tanpa amelioran dengan tinggi $58,25 \mathrm{~cm}$. Pada variabel jumlah daun sangat berbeda nyata pada perlakuan N, P, K 50\% + tanpa amelioran dengan jumlah 7,26 helai dan diikuti perlakuan N, P, K 75\% + Amelioran 1,5 t/ha dengan jumlah 6,85 helai. Perlakuan kombinasi dosis pupuk $\mathrm{N}, \mathrm{P}, \mathrm{K}$ tanpa amelioran berbeda nyata pada variabel tinggi dan jumlah daun. Hasil tersebut mengindikasikan bahwa pengaplikasian pupuk N, P, K dengan dosis rendah dibawah rekomendasi mampu meningkatkan tinggi dan jumlah daun tanaman jewawut umur muda. Pupuk N, P, K merupakan unsur hara essensial bagi tanaman, terutama pupuk $\mathrm{N}$ yang sangat dibutuhkan tanaman pada fase vegetatif. Jumlah pupuk $\mathrm{N}$ paling banyak di atmosfer namun unsur tersebut merupakan unsur yang paling sering defisien pada tanah pertanian. Peningkatan tinggi dan jumlah daun tanaman jewawut melalui aplikasi N, P, K sejalan dengan suatu percobaan bahwa pemberian dosis pupuk dengan kisaran 0-225 kg N/ha memberikan peningkatan pertumbuhan secara kuadratik pada pertumbuhan tanaman sorgum, sedangkan perlakuan tanpa amelioran tidak berbeda nyata, hal tersebut mengindikasikan bahwa pemberian amelioran dengan taraf lainnya tidak mampu memperbaiki sifat tanah salin dikarenakan paparan salinitas pada percobaan dilahan tidak hanya pada tanah namun juga pada atmosfer yang ditandai dengan tingginya uap air laut (Suminar et al. 2017).

\section{KESIMPULAN}

Karakter morfologi bibit jewawut pada lahan salin pesisir pantai menghasilkan tiga katergori bibit yaitu baik, cukup baik dan kurang baik. Aplikasi dosis pupuk N, P, K 50\% + tanpa amelioran merupakan perlakuan terbaik dan mampu menghasilkan jumlah daun dan tinggi tanaman jewawut tinggi.

\section{UCAPAN TERIMA KASIH}

Penulis mengucapkan terima kasih kepada DRPM Kemenristek Dikti atas Hibah Tesis yang diberikan sehingga kegiatan penelitian bisa dijalankan dan menghasilkan karya tulis ini.

\section{DAFTAR PUSTAKA}

Amirjani, M. R., 2010. Effect of $\mathrm{NaCl}$ on Some Physiological Parameters of Rice. EJBS. 3(1), pp. 6-16.

Anandia, R., Roslim, D. I. \& Herman., 2014. Respon Kecambah Padi (Oryza sativa L.) Solok Terhadap Cekaman Garam. JOM FMIPA, 1(2), pp. 639-643. 
Dachlan, A., Kasim, N. \& Kurnia Sari, A., 2013. Uji Ketahanan Salinitas Beberapa Varietas Jagung (Zea Mays L.) dengan Menggunakan Agen Seleksi NaCl. J Biogenesis 11. 1(1), pp. 9-17.

FAO. 2008. Plant nutrition management service.http://www.fao.orglaglagllagllıspush\[20 Mei 2019]

Gharaibeh, M. A., Eltaif, N. I. \& Shra'a, S. H., 2012. Desalination and Desodification Curves of Highly SalineSodic Soil Amended with Phosphoric Acid and by-Product Gypsum. International Journal of Environmental Science and Development, 3(1), pp. 39-42.

Hardie, M. and Doyle, R. B., 2012. Measuring Soil Salinity. Methods in molecular biology. Tasmania: Research Gate. doi: 10.1007/978-1-61779-986-0.

Iskandar, T., dan Chairunas. 2008. Palawija production in tsunami-affected soils in the Province of Nanggroe Aceh Darussalam (hlm. 119-123). Dalam Agus F and Tinning G (Eds.). 2008. Proceedings International Workshop on Post-tsunami Soil Management, 1-2 July 2008. Cisarua, Bogor, Indonesia.

Barus, J., 2013. Pemanfaatan Lahan Dibawah Tegakan Kelapadi Lampung. Jurnal Lahan Sub-optimal, 2(1), pp. 68-74. Available at: www.jlsuboptimal.unsri.ac.id.

Kurniasari, A. M., Adisyahputra \& Rosman, R., 2010. Pengaruh kekeringan pada tanah bergaram NaCl terhadap pertumbuhan tanaman nilam. Bul. Littro. 21(1), pp. 18-27.

Kusumiyati, Onggo, T. M. \& Habibah, F. A., 2017.Pengaruh Konsentrasi Larutan Garam NaCl Terhadap Pertumbuhan dan Kualitas Bibit Lima Kultivar Asparagus. Journal Hortiluktura, 27(1), pp. 79-86.

Mahdy, A. M., 2011. Soil properties and wheat growth and nutrients as affected by compost amendment under saline water irrigation. Pedosphere, 21(6), pp. 773-781.

Nurmala, T., 2003. Prospek Jawawut (Pennisetum spp.) Sebagai Tanaman Pangan Serealia Alternatif. Jurnal Bionatura, 5(1), pp. 11-20.

Pranasari, R. A., Nurhidayati, T. \& Purwani, K. I., 2012. Persaingan Tanaman Jagung (Zea mays) dan Rumput Teki (Cyperus rotundus) Pada Pengaruh Cekaman Garam (NaCl). Jurnal Sains dan Seni Its, 1(1), pp. $54-57$.

Rachman, A., Dariah, A. and Sutono, S., 2018. Pengelolaan Sawah Salin Berkadar Garam Tinggi. IAARD Press. Jakarta.

Rewald B, Shelef O, Ephrath JE, Rachmilevitch S., 2013.Adaptive plasticity of salt-stressed root systems. 6, pp. 169-202. Di dalam: Ahmad P, Azooz MM, Prasad MNV, editor. Ecophysiology and Responses of Plants under Salt Stress. London (UK): Springer.

Sirappa, M. P., dan Tim BPTP. 2015. Potensi dan Teknologi Budidaya Tanaman Jewawut (Setaria Italica) di Sulawesi Barat Pada Tahun 2014-2015. http://sulbar.litbang.pertanian.go.id/ind/index.php/infoteknologi/365-potensi-dan-teknologi-budidaya-tanaman-jewawut-setaria-italica-di-sulawesi-barat [14 November 2019]

Sopandie, D. 2013. Fisiologi Adaptasi Tanaman terhadap Cekaman Abiotik pada Ekosistem Tropika. Bogor: PT Penerbit IPB Press. 2013.

Stefhani C.A., Mumu S., and Pharmawati, K., 2013. Fitoremediasi Phospat dengan Menggunakan Tumbuhan Eceng Gondok (Eichhorniacrassipes) pada Limbah Cair Industri Kecil Pencucian Pakaian (Laundry). RekaLingkungan Jurnal Institut Teknologi Nasional, 1(1), pp. 1-11.

Suminar, R., Suwarto \& Purnawati, H., 2017. Determination of N, P, and K Fertilizer Optimum Rates for Sorghum (Sorghum bicolor [L.] Moench). Jurnal Ilmu Pertanian Indonesia, 22(1), pp. 6-12. 
Taufiq, A., Kristiono, A. and Harnowo, D., 2015. Respon Varietas Unggul Kacang Tanah terhadap Cekaman Salinitas Responses of Groundnut Varieties to Salinity Stress. Jurnal Penelitian Pertanian Tanaman Pangan, 34(2), p. 153-164.

Tazeh, E.S.E., Pazira, MR. Neyshabouri, F. Abbasi, and HZ. Abyaneh., 2013. Effects of two organic amandements on EC, SAR and soluble ions concentration in a saline sodic soil. International Journal of Biosciences, 3(9), pp. 55-68.

Zooleh, H.H., Jahansooz, M. R., Yunusa, I., Hosseini, S. M.B., Chaichi, M. R., and Jafari, A. A., 2011. Effect of alternate irrigation on root-divided foxtail millet (Setaria italica)', Australian Journal of Crop Science, 5(2), pp. 205-213. 